\title{
PENGARUH AIR GARAM SEBAGAI MEDIA PENDINGIN TERHADAP NILAI KEKERASAN PADA PROSES PENGERASAN BAJA ST 60
}

\section{Muhammad Syaifullah, Muhammad Subhan, Juanda}

Politeknik Manufaktur Negeri Bangka Belitung (POLMAN BABEL) Indonesia

Email: msyaifullah2000@gmail.com, msubhan00@yahoo.co.id, juand_pol@yahoo.com

\begin{tabular}{l}
\hline INFO ARTIKEL \\
\hline Diterima \\
25 Juli 2021 \\
Direvisi \\
05 Agustus 2021 \\
Disetujui \\
15 Agustus 2021 \\
\hline
\end{tabular}

Kata Kunci: baja st 60; quenching; media pendingin; uji kekerasan; one way Anova

\begin{abstract}
ABSTRAK
Baja St 60 merupakan baja yang termasuk kedalam baja karbon sedang. Baja St 60 memiliki kandungan unsur karbon 0,44\% memungkinkan dapat dilakukan proses pengerasan dengan perlakuan panas (Heat Treatment) yang sesuai. Penelitian ini bertujuan untuk mengetahui pengaruh air garam $(\mathrm{NaCl})$ dan air garam $\left(\mathrm{MgCl}_{2}\right)$ sebagai media pendingin terhadap nilai kekerasan pada proses pengerasan baja St 60. Penelitian ini menggunakan metode quenching. Quenching menggunakan media pendingin tertentu dapat mempengaruhi sifat kekerasan dari baja St 60 tersebut. Proses quenching dalam penelitian ini menggunakan suhu $850^{\circ}$ ditahan selama 35 menit kemudian didinginkan secara cepat kedalam media pendingin. Media pendingin yang digunakan dalam penelitian ini adalah larutan garam dapur $(\mathrm{NaCl}) 35 \%$ dan $40 \%$ kemudian larutan garam Magnesium Chloride $\left(\mathrm{MgCl}_{2}\right) 35 \%$ dan $40 \%$. Setelah dilakukan proses quenching, baja St 60 dilakukan pengujian kekerasan menggunakan metode rockwell. Setelah pengujian, nilai kekerasan di analisis data menggunakan metode one way ANOVA. Hasil penelitian menunjukkan bahwa nilai kekerasan sebelum perlakuan panas yaitu (14.5 HRC) dan nilai kekerasan setelah perlakuan panas dengan empat variasi media pendingin yaitu air garam dapur $(\mathrm{NaCl}) 35 \%$ sebesar (40.5 HRC), air garam dapur $(\mathrm{NaCl}) 40 \%$ sebesar (43.4 $\mathrm{HRC})$, air garam magnesium chloride $\left(\mathrm{MgCl}_{2}\right) 35 \%$ sebesar (43.7 HRC) dan air garam magnesium chloride $\left(\mathrm{MgCl}_{2}\right) 40 \%$ sebesar $(46.2 \mathrm{HRC})$. Dari keempat media pendingin yang memberikan hasil kekerasan lebih baik pada material baja St 60 yaitu media pendingin air garam magnesium chloride $\left(\mathrm{MgCl}_{2}\right) 40 \%$ dengan nilai kekerasan sebesar (46.2 HRC).
\end{abstract}

\section{ABSTRACT}

St. 60 steel is a steel that belongs to medium carbon steel. St. 60 steel has a carbon element content of $0.44 \%$ allowing the hardening process with the appropriate heat treatment. This

How to cite:

E-ISSN:

Published by:
Syaifullah, M., Subhan, M., \& Juanda, J. (2021) Pengaruh Air Garam Sebagai Media Pendingin Terhadap Nilai Kekerasan Pada Proses Pengerasan Baja ST 60. Jurnal Syntax Admiration 2(8). https://doi.org/10.46799/jsa.v2i8.292

2722-5356

Ridwan Institute 
study aims to find out the influence of (Nacl) brine and (MgCl2) brine as a cooling medium against the hardness value in the steel hardening process of St. 60. This research uses quenching method. Quenching using certain cooling media can affect the hardness of the St. 60 steel. The quenching process in this study using a temperature of $850^{\circ}$ was held for 35 minutes then cooled quickly into the cooling media. The cooling media used in this study was 35\% kitchen salt solution ( $\mathrm{NaCl})$ and 40\% then Magnesium Chloride salt solution (MgCl2) 35\% and 40\%. After the quenching process, St 60 steel was tested hard using rockwell method. After testing, the hardness value in the data analysis uses the one way ANOVA method. The results showed that the value of violence before heat treatment is $(14.5$ $H R C)$ and the value of violence after heat treatment with four variations of cooling media namely kitchen brine $(\mathrm{NaCl}) 35 \%$ by (40.5 HRC), kitchen brine ( $\mathrm{NaCl}) 40 \%$ (43.4 HRC),

Keywords: steel st magnesium chloride brine $\left(\mathrm{MgCl}_{2}\right) \quad 35 \%$ (43.7 $\mathrm{HRC}$ ) and 60; quenching; magnesium chloride brine ( $\mathrm{MgCl}$ ) $40 \%$ (46.2 HRC). Of the cooling media, four cooling media that give better hardness result in steel hardness test; one material St 60 is magnesium chloride salt water cooling media way Anova ( $\mathrm{MgCl2}$ ) 40\% with a hardness value of (46.2 HRC).

\section{Pendahuluan}

Seiring dengan perkembangan zaman dan teknologi yang semakin hari semakin maju terutama pada produksi manufaktur. Salah satu produksi dengan bahan bakunya baja sedang yang biasa digunakan untuk pembuatan alat-alat perkakas, roda gigi atau komponen-komponen otomotif.

Hal yang harus dilakukan untuk memperoleh sifat mekanis baja yang baik terutama pada nilai kekerasan, maka dilakukan proses perlakuan panas quenching pada baja. Perlakuan panas adalah suatu proses pemanasan dan pendinginan dalam keadaan padat untuk mengubah sifat-sifat mekaniknya. Baja dapat dikeraskan sehingga tahan aus dan kemampuan memotong meningkat atau dapat dilunakan untuk memudahkan proses pemesinan lanjut (Mustofa, 2016). Tujuan perlakuan panas adalah untuk memberi sifat yang lebih sempurna pada bahan. Perlakuan panas dapat mengubah sifat baja dengan cara mengubah ukuran dan bentuk butir-butirannya, juga mengubah unsur pelarutnya dalam jumlah yang kecil. Bentuk butirannya dapat diubah dengan cara dipanaskan pada suhu di atas suhu rata-rata (Nur, 2017).

Quenching merupakan pendinginan secara cepat suatu logam dengan pencelupan pada media pendingin. Kekerasan maksimum dapat terjadi dengan mendinginkan secara mendadak sampel yang telah dipanaskan sehingga mengakibatkan perubahan struktur mikro (Mustofa, 2016). Tujuan utama dari proses quenching ini adalah untuk menghasilkan baja dengan sifat kekerasan tinggi (Fhadillah et al., 2019).

Baja St 60 merupakan jenis baja karbon menengah dengan memiliki kandungan karbon sebesar 0,5012\%. Dengan kandungan karbonnya memungkinkan baja untuk 
dikeraskan sebagian dengan proses perlakuan panas (heat treatment) yang sesuai (Putra et al., 2018).

Pada penelitian sebelumnya, telah dilakukan penelitian tentang analisa sifat mekanis baja St 60 setelah carburizing menggunakan arang batok katalis $\mathrm{BaCO} 3$ dan quenching dengan oli dan air garam (Fhadillah et al., 2019), dan hasil yang didapat dari penelitian tersebut menunjukkan bahwa nilai kekerasan Vickers pada baja St 60 semakin keras pada carburizing quenching air garam tingkat kekerasnya naik sebesar 431,68 VHN dan nilai quenching oli dan tanpa quenching masing-masing memiliki nilai sebesar 10,25\% dan 24,55\% lebih kecil dari carburizing quenching air garam.

Pada penelitian lainnya telah dilakukan tentang analisa uji kekerasan pada poros baja St 60 dengan media pendingin berbeda (Furqon \& Firman, 2016), dan didapat hasil nilai kekerasan sebelum perlakuan panas yaitu 112,4 HB dan nilai kekerasan sesudah perlakuan panas dengan tiga variasi media pendingin yaitu air (110,2 HB), udara $(94,8$ HB), dan oli mesran SAE 40 (119,4 HB). Dari ketiga media pendingin yang memberikan hasil kekerasan lebih baik pada material baja St 60 yaitu media pendingin oli mesran SAE 40 dan didapatkan nilai kekerasan rata-ratanya 119,4 HB.

Pada penelitian yang telah dilakukan tentang pengaruh kadar garam dapur $(\mathrm{NaCl})$ dalam media pendingin terhadap tingkat kekerasan pada proses pengerasan baja St 60 (Aziza, 2017), dan hasil yang didapat Baja St 60 yang telah mengalami proses hardening dengan media pendingin larutan garam $20 \% \mathrm{NaCl}$ mempunyai nilai kekerasan rata-rata $265 \mathrm{HV}$, untuk baja dengan media pendingin larutan garam $25 \%$ memiliki angka kekerasan rata-rata sebesar $278 \mathrm{HV}$, sedangkan untuk baja dengan media pendingin larutan garam 30\% mempunyai angka kekerasan rata-rata $311 \mathrm{HV}$, hal ini menunjukan bahwa semakin besar larutan garamnya maka semakin tinggi nilai kekerasannya.

Penelitian ini dilakukan untuk mendapatkan data tentang "Pengaruh Air Garam Sebagai Media Pendingin Terhadap Nilai Kekerasan Pada Proses Pengerasan Baja St 60". Dengan adanya penelitian ini, maka diharapkan dapat bermanfaat dalam bidang industri manufaktur.

Baja karbon atau Carbon Steel merupakan salah satu jenis baja paduan yang terdiri atas kandungan besi $(\mathrm{Fe})$ dan kandungan karbon $(\mathrm{C})$. Dalam baja karbon ini besi merupakan kandungan unsur dasar dan karbon sebagai kandungan unsur paduan utamanya. Dalam proses pembuatan baja akan ditambahkan kandungan unsur kimia lainnya untuk menyesuaikan dengan sifat baja yang diinginkan. Unsur kimia lainnya yang biasa digunakan adalah seperti sulfur (S), fosfor (P), silikon (Si) dan mangan (Mn) (Santoso \& Suhardiman, 2019).

Kandungan karbon (C) yang terdapat pada baja menentukan tingkatan dari baja itu sendiri. Baja karbon memiliki kandungan unsur karbon dalam besi sebesar 0,2\% sampai 2,14 \%. Dimana kandungan unsur karbon tersebut digunakan sebagai unsur pengeras dalam sturktur baja (Santoso \& Suhardiman, 2019). Semakin tinggi kandungan unsur karbon, maka baja akan semakin keras dan kuat dengan perlakuan panas, namun keuletannya akan semakin berkurang. Pengaplikasian baja karbon pada dunia industri 
sering digunakan sebagai bahan baku pembuatan alat-alat perkakas, bagian komponen mesin, bahkan struktur bangunan dan lain sebagainya.

Baja karbon tinggi merupakan baja karbon yang memiliki kandungan karbon berkisar antara 0,6 \% sampai 1,4\% dibandingkan berat besi yang digunakan pada baja tersebut. Baja karbon tinggi memiliki sifat dengan tingkat kekerasan yang tinggi namun memiliki keuletan dari baja karbon tinggi sangat kecil. Baja karbon tinggi biasanya digunakan untuk alat-alat yang memerlukan tingkat ketahanan yang tinggi terhadap gesekan dalam penggunaannya akan menerima atau mengalami ketahanan panas, misalnya seperti bearing, mata bor, mata pahat, gergaji, kikir dan lain sebagainya (Yusman, 2018).

Baja St 60 merupakan jenis baja karbon menengah dengan memiliki kandungan karbon sebesar 0,5012\%. Dengan kandungan karbonnya memungkinkan baja untuk dikeraskan sebagian dengan proses perlakuan panas (heat treatment) yang sesuai (Putra et al., 2018). Baja St 60 dijelaskan secara umum merupakan baja karbon sedang dengan persentase kandungan karbon pada besi sebesar 0,3\% $\mathrm{C}-0,59 \% \mathrm{C}$ dengan titik didih $1550^{\circ} \mathrm{C}$ dan titik lebur $2900^{\circ} \mathrm{C}$, disebut juga baja keras, banyak digunakan untuk pembuatan tangki, perkapalan, jembatan, dan dalam permesinan (Furqon \& Firman, 2016).

Pengkodean baja St 60 berasal dari standarisasi jerman atau biasa dikenal dengan DIN (Deutsches Institut for Normung). St sendiri merupakan singkatan dari steel (baja) dan angka dibelakang St merupakan kode yang menunjukkan besar kekuatan Tarik maksimumnya. St 60 merupakan baja yang mempunyai kekuatan tarik hingga 600 $\mathrm{kg} / \mathrm{mm}^{2}$ (Iriandoko et al., 2020).

Untuk memperbaiki sifat-sifat mekanis pada sebuah logam dapat dilakukan dengan adanya perlakuan, dimana perlakuan yang dimaksud adalah proses perlakuan panas (heat treatment). Perlakuan panas (heat treatment) adalah suatu proses mengubah sifat mekanis logam dengan cara mengubah struktur mikro melalui proses pemanasan dan pengaturan kecepatan pendinginan dengan atau tanpa mengubah komposisi kimia (Slamet \& Moelyono, 2000).

Perlakuan panas adalah suatu proses pemanasan dan pendinginan logam dalam keadaan padat untuk mengubah sifat-sifat fisis logam tersebut (Santoso \& Suhardiman, 2019). Perlakuan panas sendiri adalah penggabungan atau kombinasi dari proses pemanansan dan proses pendinginan pada suatu bahan material seperti logam dan baja (Yusman, 2018). Tujuan dari proses perlakuan panas adalah untuk meningkatkan keuletan, menghilangkan tegangan internal (internal stress), menghaluskan ukuran butir kristal dan meningkatkan kekerasan atau tegangan tarik logam (Handoyo, 2015). Jadi dapat disimpulkan bahwa perlakuan panas (Heat treatment) adalah suatu proses kombinasi dari proses pemanasan dan pendinginan material secara terkontrol dengan tujuan untuk memperbaiki, menghasilkan atau mengubah sifat-sifat pada logam maupun baja. Proses perlakuan panas dilakukan untuk mendapatkan sifat-sifat tertentu sesuai dengan keinginan dan kebutuhan pada baja tersebut. 


\section{Metode Penelitian}

Adapun metode yang digunakan adalah model eksperimen murni dengan dua buah variabel yang masing-masing akan dilakukan uji hipotesis secara matematis dengan analisis statistik one-way ANOVA (Fitrayudha et al., 2020). Langkah awal untuk memulai penelitian yaitu studi literatur yang didapat dari $e$-book, internet, artikel dan jurnal ilmiah. Langkah selanjutnya memahami studi literatur dan menjadikannya sebagai referensi. Sehingga dengan adanya studi literatur dapat digunakan untuk memperkuat argumen tentang penelitian yang di ajukan. Rincian langkah-langkah tersebut dapat ditunjukkan pada gambar 1 sebagai berikut:

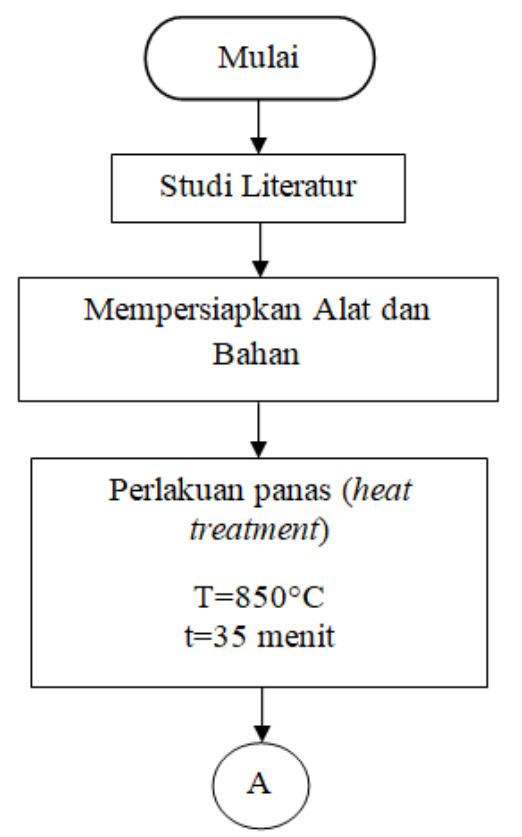

Gambar 1

Flowchart Penelitian 


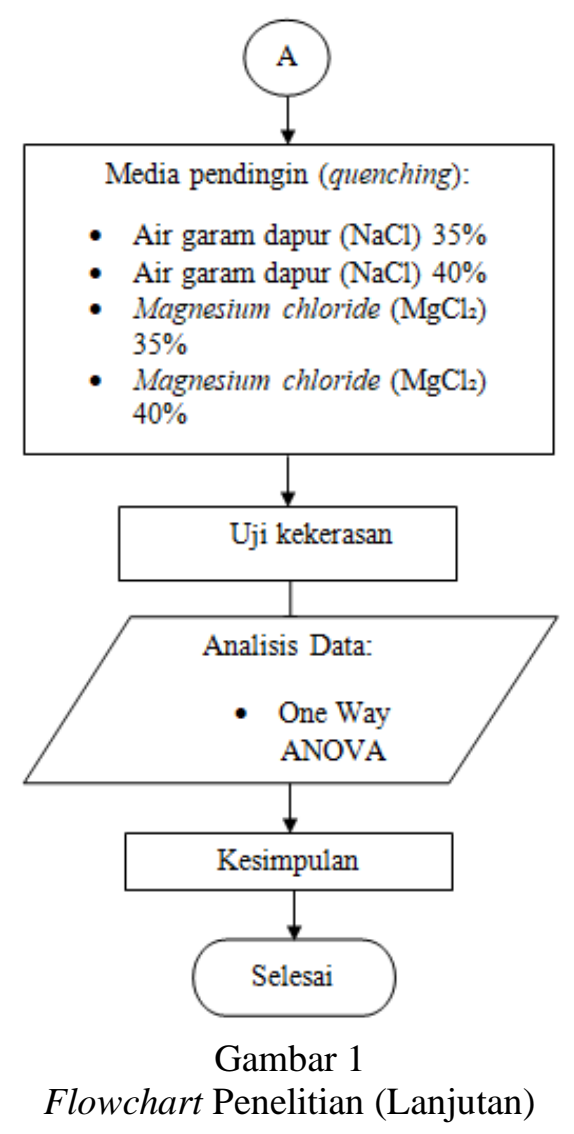

\section{Tempat dan Lokasi Penelitian}

Tempat dan lokasi penelitian ini dilakukan di Laboratorium Material dan Laboratorium Politeknik Manufaktur Negeri Bangka Belitung.

\section{Analisis Data}

Analisis data yang digunakan dalam penelitian ini adalah Analisis of Varians (ANOVA) Satu Arah (Marpaung et al., 2017). Langkah-langkah yang dilakukan dalam one way ANOVA adalah sebagai berikut:

a. Menentukan Hipotesis

Hipotesis yang digunakan dalam penelitian ini adalah sebagai berikut:

- H0 : Tidak terdapat pengaruh perlakuan

- H1 : Terdapat pengaruh perlakuan

b. Menentukan $(\alpha)$

Pada penelitian ini taraf signifikansi $\alpha$ yang digunakan sebesar 5\% (0.05).

c. Menentukan Kriteria Pengujian

Kriteria uji yang digunakan dalam penelitian ini adalah sebagai berikut:

- Jika nilai Fhitung < nilai Ftabel $(\alpha=5 \%)$, maka hasil penelitian menunjukkan bahwa perlakuan tidak berpengaruh terhadap kekerasan dengan kata lain $\mathrm{H} 0$ diterima dan $\mathrm{H} 1$ ditolak.

- Jika nilai Fhitung > nilai Ftabel $(\alpha=5 \%)$, maka hasil penelitian menunjukkan bahwa perlakuan berpengaruh terhadap kekerasan dengan kata lain H0 ditolak dan $\mathrm{H} 1$ diterima 


\section{d. Statistik Uji}

Dalam statistik uji maka langkah-langkah yang dilakukan adalah sebagai berikut:

1) Mencari Jumlah Kuadrat (JK)

2) Mencari Derajat Bebas $(\mathrm{db})=\mathrm{df}=\mathrm{v}$

3) Mencari Kuadrat Tengah (KT)

4) Membuat Tabel

5) Mencari Ftabel

6) Membandingkan Fhitung dengan Ftabel

\section{Hasil dan Pembahasan}

\section{A. Hasil Penelitian}

Dalam penelitian ini terdapat beberapa tahapan proses yang akan dilakukan mulai dari persiapan spesimen, perlakuan panas, dan pengujian. Adapun langkahlangkah yang dilakukan sebagai berikut:

a. Persiapan spesimen

Persiapan spesimen ini dimulai dari:

- Pembuatan spesimen dilakukan dengan menggunakan mesin gergaji potong DOALL Model C-916. Potong spesimen dengan ukuran panjang $20 \mathrm{~mm}$ dan diameter $25 \mathrm{~mm}$. Jumlah spesimen yang akan dibuat sebanyak 13 Pcs. Untuk pembuatan spesimen dapat ditunjukkan seperti pada gambar 1 di bawah ini:

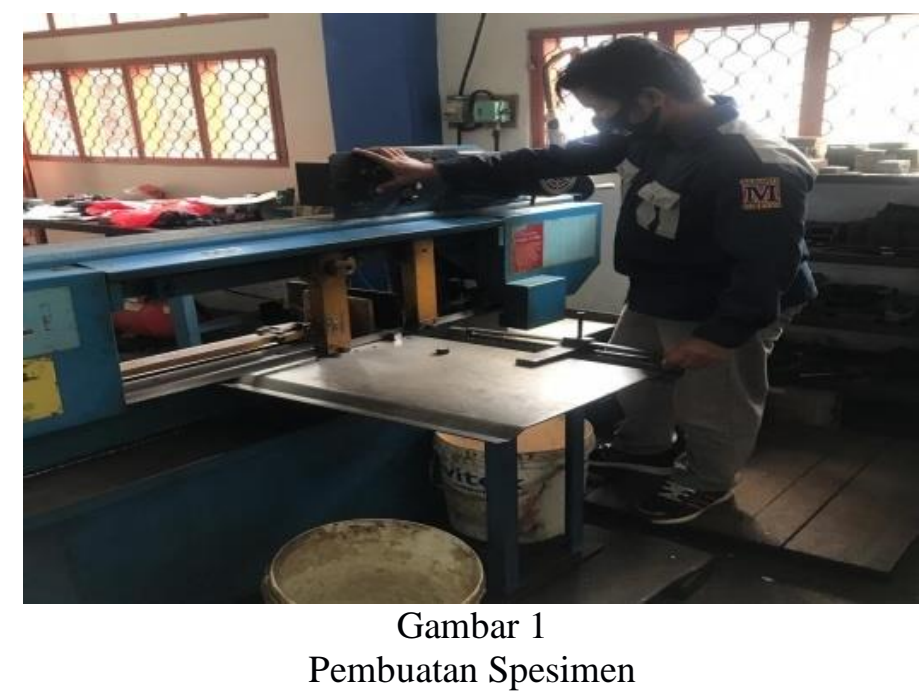

- Mengikir spesimen setelah selesai dipotong untuk menghilangkan sisi tajam sisa pemotongan.

- Mengikat spesimen dengan kawat agar mempermudahkan dalam pengangkatan dan pencelupan ke media pendingin. Untuk proses mengikat spesimen dapat ditunjukkan seperti pada gambar 2 sebagai berikut: 


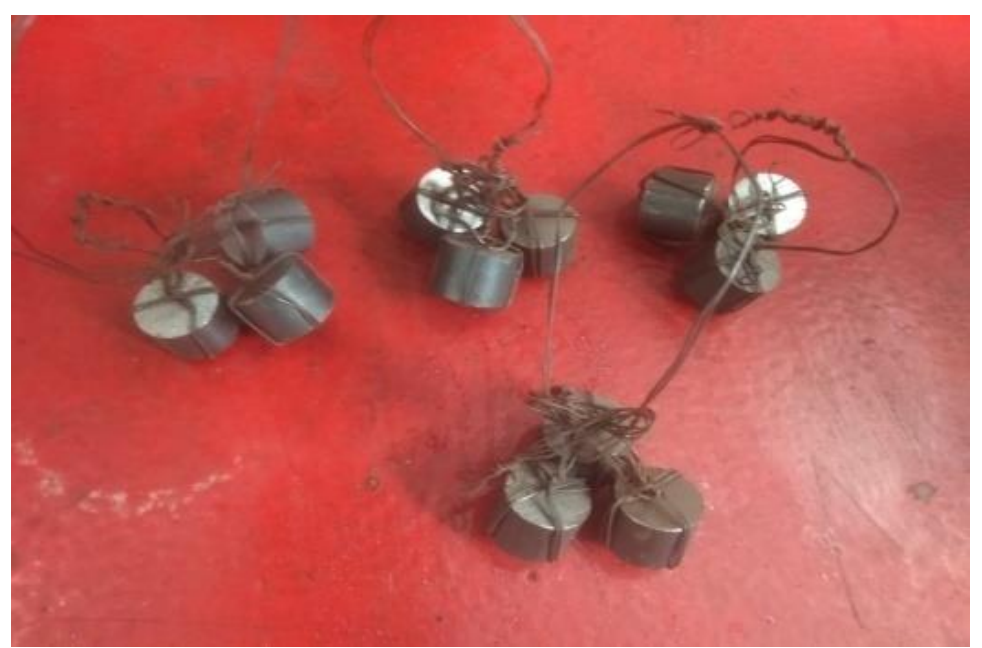

Gambar 2

Mengikat Spesimen

b. Perlakuan panas

Ada beberapa tahapan yang dilakukan dalam proses perlakuan panas, yaitu:

- Menyiapkan media pendingin yang akan digunakan dalam penelitian. Hal yang perlu disiapkan adalah 4 liter air sebanyak 4 wadah, garam yang akan dipakai sebagai media pendingin yaitu garam dapur $(\mathrm{NaCl})$ dengan kadar garam 35\% dan $40 \%$ kemudian garam Magnesium Chloride $\left(\mathrm{MgCl}_{2}\right)$ dengan kadar garam $35 \%$ dan $40 \%$. Selanjutnya masing-masing garam sesuai dengan kadarnya dicampur dengan wadah yang sudah berisi air dan diaduk hingga merata. Untuk larutan garam yang digunakan dalam penelitian ini dapat ditunjukkan seperti pada gambar 3 di bawah ini:

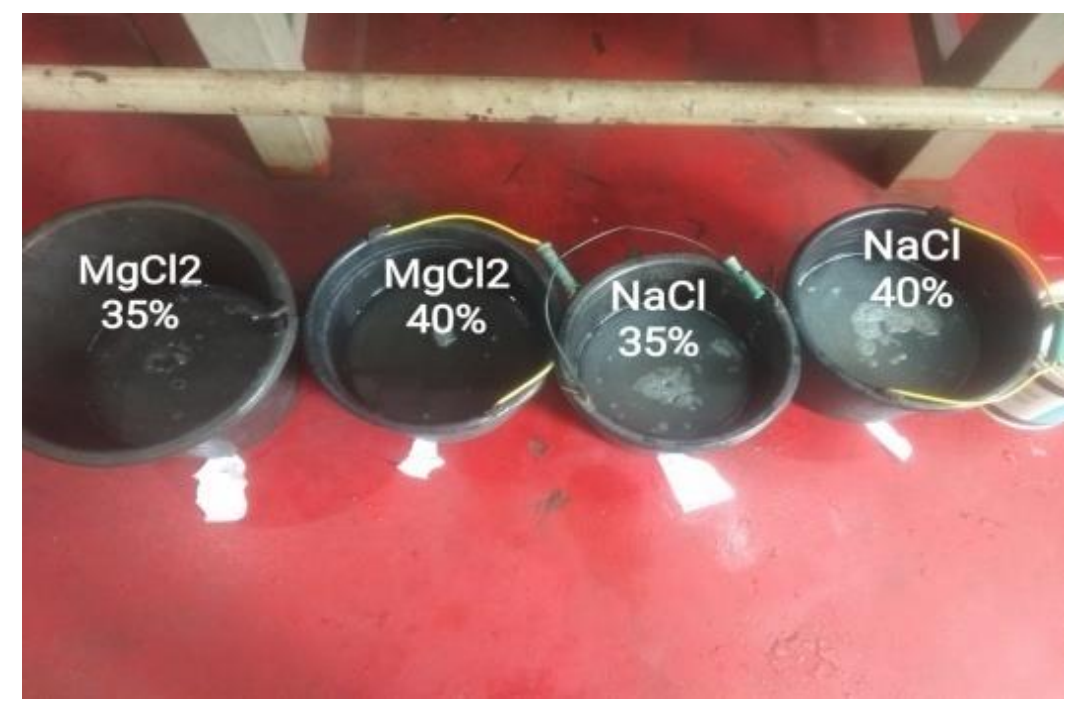

Gambar 3

Larutan Garam 
- Proses pemanasan dilakukan dengan persiapan dapur pemanas. Selanjutnya memasukan spesimen yang telah diikat dengan kawat kedalam dapur pemanas. Spesimen dipanaskan pada suhu $850^{\circ} \mathrm{C}$ dan ditahan selama 35 menit.

- Proses quenching dilakukan setelah tungku mencapai batas waktu penahanan. Spesimen didinginkan secara cepat setelah dipanaskan pada suhu $850^{\circ} \mathrm{C}$ kedalam wadah berisi larutan garam. Setelah spesimen dingin angkat spesimen dan keringkan menggunakan majun. Untuk proses pencelupan dapat ditunjukkan seperti pada gambar 4 di bawah ini:

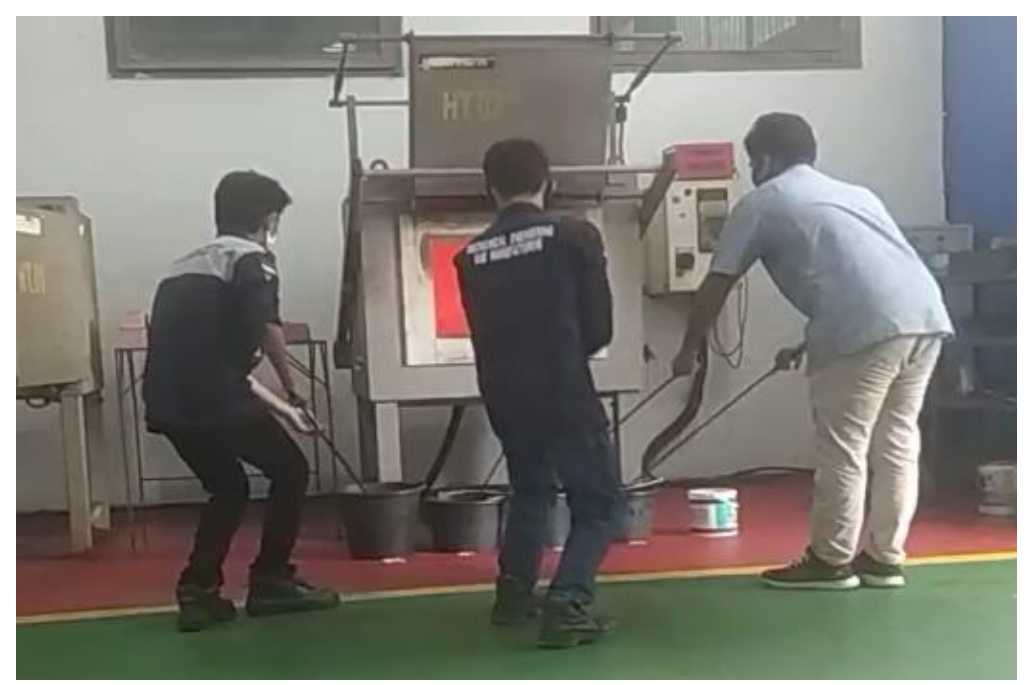

Gambar 4

Proses Pencelupan

- Setelah spesimen mencapai suhu ruangan, keringkan menggunakan majun dan bersihkan menggunakan amplas.

c. Pengujian

Dalam penelitian yang dilakukan pada baja St 60 menggunakan metode pengujian kekerasan Rockwell (Setiawan, 2014). Adapun langkah-langkah yang digunakan dalam pengujian ini sebagai berikut:

- Mempersiapkan spesimen uji yang telah di proses perlakuan panas dan dihaluskan.

- Mengatur beban pada alat uji kekerasan Rockwell sebesar 150-kgf.

- Melakukan pemasangan indentor yang berbentuk seperti diamond.

- Meletakkan spesimen pada meja uji.

- Melakukan pengujian pada spesimen dengan cara memutar tuas pada bagian bawah meja uji. Untuk proses pengujian dapat ditunjukkan seperti pada gambar 5 sebagai berikut: 


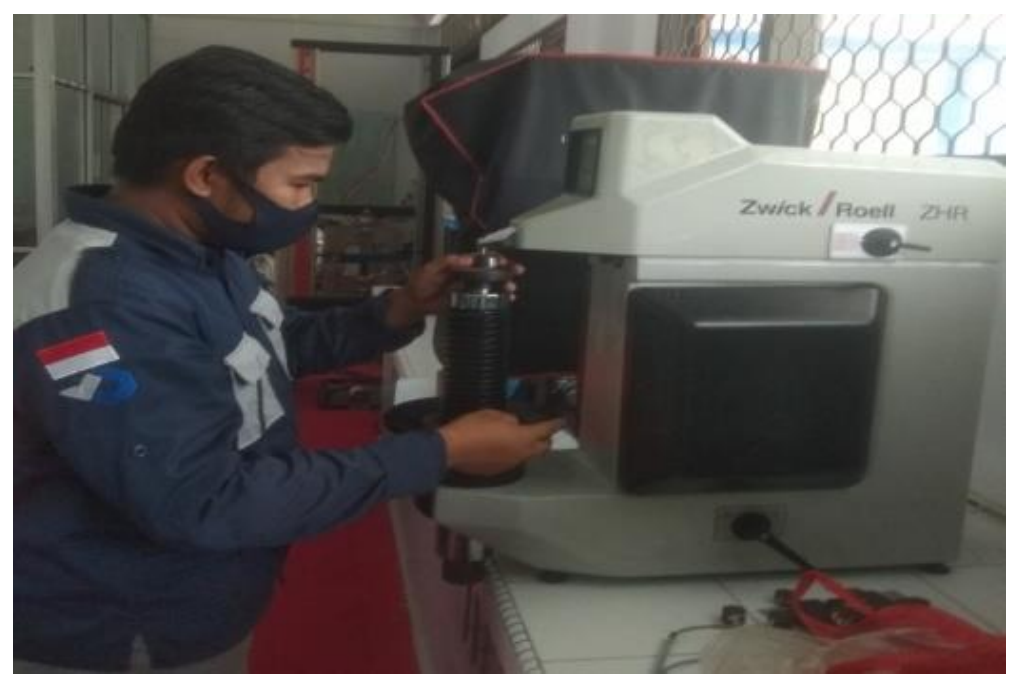

Gambar 5

Melakukan Pengujian

- Setelah itu tunggu hingga alat uji membaca nilai kekerasan spesimen.

- Setelah alat uji selesai membaca nilai kekerasan, turunkan meja uji sampai spesimen tidak menempel lagi pada indentor dengan cara memutar tuas berlawanan arah jarum jam pada bagian bawah meja uji.

- Lakukan pengulangan penitikan yang tidak terlalu jauh dari penitikan pertama sampai beberapa titik dan catat hasil nilai kekerasan yang saling mendekati.

\section{B. Pembahasan}

Adapun hasil pengujian kekerasan tanpa perlakuan (R1) dapat dilihat seperti pada tabel 1 di bawah ini:

Tabel 1

Hasil Pengujian Kekerasan Tanpa Perlakuan (R1)

\begin{tabular}{ccccc}
\hline No. & \multicolumn{3}{c}{ Banyak pengujian } & $\begin{array}{c}\text { Jumlah } \\
\text { rata-rata } \\
\text { (HRC) }\end{array}$ \\
\hline $\mathbf{1}$ & 1 & 2 & 3 & 14.5 \\
\hline
\end{tabular}

Berdasarkan tabel 1 dapat dilihat hasil pengujian kekerasan tanpa perlakuan memiliki rata-rata nilai kekerasan sebesar 14.5 HRC.

Adapun hasil pengujian kekerasan setelah perlakuan dapat dilihat seperti pada tabel 2 sebagai berikut:

Tabel 2

Hasil Pengujian Kekerasan Setelah Perlakuan

\begin{tabular}{|c|c|c|c|c|c|c|c|}
\hline \multirow[t]{2}{*}{ No } & \multirow[t]{2}{*}{ Quenching } & \multirow{2}{*}{$\begin{array}{l}\text { Nama } \\
\text { Sampel }\end{array}$} & \multicolumn{5}{|c|}{ Harga Kekerasan Rockwel (HRC) } \\
\hline & & & 1 & 2 & 3 & $\begin{array}{l}\text { Rata-rata } \\
1,2 \text { dan } 3\end{array}$ & $\begin{array}{c}\text { Rata-Rata } \\
\Sigma\end{array}$ \\
\hline \multirow[t]{3}{*}{1} & Air Garam & A1 & 39.1 & 39.1 & 41 & 39.7 & \multirow{3}{*}{40.5} \\
\hline & $\mathrm{NaCl} 35 \%$ & $\mathrm{~A} 2$ & 40 & 40.7 & 40.7 & 40.5 & \\
\hline & & $\mathrm{A} 3$ & 41.1 & 41.1 & 41.3 & 41.2 & \\
\hline 2 & Air Garam & B1 & 42.9 & 43.3 & 43.5 & 43.2 & \\
\hline
\end{tabular}




\begin{tabular}{|c|c|c|c|c|c|c|c|}
\hline \multirow{2}{*}{\multicolumn{2}{|c|}{$\mathrm{NaCl} 40 \%$}} & B2 & 42.8 & 43.1 & 44.1 & 43.3 & \multirow[t]{2}{*}{43.4} \\
\hline & & B3 & 42.3 & 44.4 & 44.6 & 43.8 & \\
\hline \multirow[t]{3}{*}{3} & Air Garam & $\mathrm{C} 1$ & 43.3 & 43.3 & 44.1 & 43.6 & \multirow{3}{*}{43.7} \\
\hline & $\mathrm{MgCl}_{2} 35 \%$ & $\mathrm{C} 2$ & 43 & 43.6 & 43.8 & 43.5 & \\
\hline & & C3 & 43.8 & 44.2 & 44.4 & 44.1 & \\
\hline \multirow{3}{*}{4} & Air Garam & D1 & 45.1 & 45.5 & 47.3 & 46 & \multirow{3}{*}{46.2} \\
\hline & $\mathrm{MgCl}_{2} 40 \%$ & D2 & 45.3 & 46.5 & 46.9 & 46.2 & \\
\hline & & D3 & 45.5 & 46.4 & 47.2 & 46.4 & \\
\hline
\end{tabular}

Berdasarkan tabel 2 dapat dilihat air garam dapur $(\mathrm{NaCl}) 35 \%$ memiliki rata-rata nilai kekerasan sebesar $40.5 \mathrm{HRC}$, air garam dapur $(\mathrm{NaCl}) 40 \%$ memiliki rata-rata nilai kekerasan sebesar $43.4 \mathrm{HRC}$, air garam magnesium chloride $\left(\mathrm{MgCl}_{2}\right) 35 \%$ memiliki rata-rata nilai kekerasan sebesar $43.7 \mathrm{HRC}$ dan air garam magnesium chloride $\left(\mathrm{MgCl}_{2}\right) 40 \%$ memiliki rata-rata nilai kekerasan sebesar 46.2 HRC.

Langkah-langkah yang dilakukan dalam menghitung one way ANOVA adalah sebagai berikut:

d. Hipotesis

H0: Tidak terdapat perbedaan yang signifikan terhadap pengaruh media pendingin pada hasil penelitian yang dilakukan terhadap sampel setelah dilakukan pengujian kekerasan pada spesimen baja St 60 .

H1: Terdapat perbedaan yang signifikan terhadap pengaruh media pendingin pada hasil penelitian yang dilakukan terhadap sampel setelah dilakukan pengujian kekerasan pada baja St 60 .

e. Menentukan $(\alpha)$

$\alpha=5 \%(0.05)$

f. Kriteria uji

- Jika nilai Fhitung < nilai Ftabel $(\alpha=5 \%)$, maka hasil penelitian menunjukkan bahwa tidak terdapat pengaruh terhadap kekerasan dengan kata lain H0 diterima dan $\mathrm{H} 1$ ditolak.

- Jika nilai Fhitung > nilai Ftabel $(\alpha=5 \%)$, maka hasil penelitian menunjukkan bahwa terdapat pengaruh terhadap kekerasan dengan kata lain $\mathrm{H} 0$ ditolak dan H1 diterima.

g. Statistika uji

Fhitung $=\frac{s^{2} \text { perlakwan }}{s^{2} \text { galat }}$

Adapun perhitungan one way ANOVA yang digunakan dapat dilihat seperti pada tabel 3 di bawah ini:

Tabel 3

Perhitungan One Way ANOVA

\begin{tabular}{lcccccccc}
\hline No. & $\begin{array}{c}\text { NaCl } \\
\mathbf{3 5 \%} \\
(\mathbf{A})\end{array}$ & $\begin{array}{c}\mathbf{N a C l} \\
\mathbf{4 0 \%} \\
(\mathbf{B})\end{array}$ & $\begin{array}{c}\mathrm{MgCl} \\
\mathbf{3 5 \%} \\
(\mathbf{C})\end{array}$ & $\begin{array}{c}\mathbf{M g C l}_{\mathbf{2}} \\
\mathbf{4 0 \%} \\
(\mathbf{D})\end{array}$ & $\mathbf{A}^{\mathbf{2}}$ & $\mathbf{B}^{\mathbf{2}}$ & $\mathbf{C}^{\mathbf{2}}$ & $\mathbf{D}^{\mathbf{2}}$ \\
\hline $\bar{x} \mathbf{1}$ & 39.7 & 43.2 & 43.6 & 46 & $\begin{array}{l}1576.0 \\
9\end{array}$ & $\begin{array}{l}1866.2 \\
4\end{array}$ & $\begin{array}{l}1900.9 \\
6\end{array}$ & 2116 \\
\hline
\end{tabular}


Muhammad Syaifullah, Muhammad Subhan, Juanda

\begin{tabular}{|c|c|c|c|c|c|c|c|c|}
\hline $\bar{x} 2$ & 40.5 & 43.3 & 43.5 & 46.2 & $\begin{array}{l}1640.2 \\
5\end{array}$ & $\begin{array}{l}1874.8 \\
9\end{array}$ & $\begin{array}{l}1892.2 \\
5 \\
\end{array}$ & $\begin{array}{l}2134 \\
.4\end{array}$ \\
\hline $\bar{x} \mathbf{3}$ & 41.2 & 43.8 & 44.1 & 46.4 & $\begin{array}{l}1697.4 \\
4\end{array}$ & $\begin{array}{l}1918.4 \\
4\end{array}$ & $\begin{array}{l}1944.8 \\
1 \\
\end{array}$ & $\begin{array}{l}2152 \\
.96 \\
\end{array}$ \\
\hline$\Sigma$ & 121.4 & 130.3 & 131.2 & 138.6 & $\begin{array}{l}4913 . \\
78\end{array}$ & $\begin{array}{l}5659 . \\
57 \\
\end{array}$ & $\begin{array}{l}5738 . \\
02 \\
\end{array}$ & $\begin{array}{l}6403 \\
.4 \\
\end{array}$ \\
\hline Total & \multicolumn{4}{|c|}{521.5} & \multicolumn{4}{|c|}{22714.77} \\
\hline$\Sigma^{2}$ & $\begin{array}{l}14737 . \\
96\end{array}$ & $\begin{array}{l}16978 . \\
09\end{array}$ & $\begin{array}{l}17213 . \\
44\end{array}$ & $\begin{array}{l}19209 . \\
96\end{array}$ & & & & \\
\hline Total & 68139.4 & & & & & & & \\
\hline
\end{tabular}

1) Mencari Jumlah Kuadrat (JK)

$$
\begin{aligned}
(\mathrm{FK})= & \frac{521.5^{2}}{12}=22663.52 \\
(\mathrm{Jk} \text { perlakuan })= & \frac{121.4^{2}+130.3^{2}+131.2^{2}+138.6^{2}}{3}-\mathrm{FK} \\
= & \frac{68139.45}{3}-22663.52=49.63 \\
\left(\mathrm{JK}_{\text {total }}\right)= & 1576.09+1866.24+1900.96+2116+1640.25+1874.89+1892.25 \\
+ & 2134.4+1697.44+1918.44+1944.81+2152.96+4913.78+ \\
& 5659.57+5738.02+6403.4-\mathrm{FK} \\
= & 51.25
\end{aligned}
$$

2) Mencari Derajat Bebas $(\mathrm{db})=\mathrm{df}=\mathrm{v}$

Vtotal $=\mathrm{nk}^{-} 1=\left(3^{\times}\right)^{-} 1=11$

Vperlakuan $\left(\mathrm{V}_{1}\right)=\mathrm{k}^{-} 1=4^{-}-1=3$

Vgalat $\left(V_{2}\right)=n k-k=(3 \times 4)-4=12-4=8$

3) Mencari Kuadrat Tengah (KT)

KTperlakuan $=\mathrm{S}^{2}$ perlakuan $=\frac{49,63}{3}=16.54$

KTgalat $=S^{2}$ galat $=\frac{1.62}{8}=0.2$

Fhitung $=\frac{\frac{s^{2} \text { perlakwan }}{s^{2} \text { galat }}}{=\frac{16.54}{0.2}}=82.7$

4) Membuat Tabel

Adapun tabulasi ragam one way ANOVA yang didapatkan dari hasil perhitungan dapat dilihat seperti pada tabel 4 di bawah ini: 
Tabel 4

Tabulasi Ragam One Way ANOVA

\begin{tabular}{|c|c|c|c|c|c|}
\hline $\begin{array}{c}\text { Sumber } \\
\text { keragaman }\end{array}$ & $\begin{array}{c}\text { Jumlah } \\
\text { Kuadrat (JK) }\end{array}$ & $\begin{array}{c}\text { Derajat } \\
\text { Bebas }(\mathbf{d b})\end{array}$ & $\begin{array}{c}\text { Kuadrat } \\
\text { Tengah (KT) } \\
\end{array}$ & Fhit & $\begin{array}{c}\text { Taraf } \\
\text { Signifikansi }(\alpha)\end{array}$ \\
\hline Perlakuan & 49.63 & 3 & 16.54 & & \\
\hline Galat & 1.62 & 8 & 0.2 & 82.7 & $5 \%(0.05)$ \\
\hline Total & 51,25 & 11 & & & \\
\hline
\end{tabular}

Untuk perhitungan ANOVA software analisis dapat dilihat seperti pada tabel 5 di bawah ini:

Tabel 5

Perhitungan ANOVA Software Analisis

\begin{tabular}{cccccc}
\hline Source & DF & SS & MS & F & P \\
\hline Media Pendingin & 3 & 49.629 & 16.543 & 81.69 & 0.000 \\
Error & 8 & 1.620 & 0.202 & & \\
Total & 11 & 51.249 & & & \\
\hline
\end{tabular}

Berdasarkan tabel 4 dan tabel 5 dapat dilihat bahwa perbandingan antara perhitungan langsung dengan perhitungan software tidak memiliki perbedaan yang jauh antara nilai $F$.

5) Menentukan Ftabel

$F_{\text {tabel }}=\mathrm{F}(\alpha ;$ df perlakuan, df galat $)$

$\mathrm{F}(0.05 ; 3 ; 8)=4.07$

6) Membandingkan Fhit dan Ftabel

Setelah didapat nilai Fhitung $82.7>$ Ftabel 4.07, maka hasil penelitian menunjukkan bahwa terdapat pengaruh terhadap kekerasan dengan kata lain $\mathrm{H0}$ diterima dan H1 ditolak. Dimana H1 menyatakan terdapat perbedaan yang signifikan terhadap pengaruh media pendingin pada hasil penelitian yang dilakukan terhadap sampel setelah dilakukan pengujian kekerasan pada baja St 60 (Matien, 2016).

\section{Kesimpulan}

Berdasarkan dari hasil pengujian serta analisis data yang telah dilakukan, maka dapat disimpulkan beberapa hal yaitu: 1) Nilai kekerasan sebelum perlakuan panas yaitu (14.5 HRC) dan nilai kekerasan setelah perlakuan panas dengan empat variasi media pendingin yaitu air garam dapur $(\mathrm{NaCl}) 35 \%$ sebesar (40.5 HRC), air garam dapur $(\mathrm{NaCl}) 40 \%$ sebesar (43.4 HRC), air garam magnesium chloride $\left(\mathrm{MgCl}_{2}\right) 35 \%$ sebesar (43.7 HRC) dan air garam magnesium chloride $\left(\mathrm{MgCl}_{2}\right) 40 \%$ sebesar (46.2 HRC). Dari keempat media pendingin yang memberikan hasil kekerasan lebih baik pada material baja St 60 yaitu media pendingin air garam magnesium chloride $\left(\mathrm{MgCl}_{2}\right) 40 \%$ dengan nilai kekerasan sebesar (46.2 HRC). 2) Terdapat pengaruh setiap kenaikan \% pada garam dalam media pendingin terhadap nilai kekerasan pada proses pengerasan baja St 60. Dimana semakin besar \% garam dalam media pendingin, maka semakin tinggi pula nilai kekerasannya. 


\section{BIBLIOGRAFI}

Aziza, Y. (2017). Pengaruh kadar garam dapur $(\mathrm{NaCl})$ dalam media pendingin terhadap tingkat kekerasan pada proses pengerasan baja ST-60. Jurnal Teknologi Terapan: G-Tech, 1 (1), 18-25. Google Scholar

Fhadillah, A., Budiarto, U., \& Santosa, A. W. B. (2019). Analisa Sifat Mekanis Baja ST 60 Setelah Carburizing Menggunakan Arang Batok Katalis BaCO3 Dan Quenching Dengan Oli Dan Air garam. Jurnal Teknik Perkapalan, 7 (1). Google Scholar

Fitrayudha, A., Fajrin, J., \& Anshari, B. (2020). Analisis Sifat Mekanis Komposit Polyester Sisal Menggunakan Metode Anova. Media Bina Ilmiah, 14 (7), 28172824. Google Scholar

Furqon, G. R., \& Firman, M. (2016). Analisa Uji Kekerasan pada Poros Baja ST 60 dengan Media Pendingin yang Berbeda. Al-Jazari Jurnal Ilmiah Teknik Mesin, 1 (1). Google Scholar

Handoyo, Y. (2015). Pengaruh Quenching Dan Tempering Pada Baja Jis Grade S45C Terhadap Sifat Mekanis Dan Struktur Mikro Crankshaft. Jurnal Ilmiah Teknik Mesin Unisma" 45" Bekasi, 3 (2), 97782. Google Scholar

Iriandoko, H., Akbar, A., \& Sindy Pramesty, Y. (2020). Pengaruh Heat Treament Baja St 60 Terhadap Nilai Kekerasan Dengan Media Pendingin Asam Cuka. Semnas Iv, 4 (1), 1-6. Google Scholar

Marpaung, J. L., Lumintang, R. C. A., \& Sutrisno, A. (2017). Penerapan metode anova untuk analisis sifat mekanik komposit serabut kelapa. Jurnal Online Poros Teknik Mesin Unsrat, 6 (2). Google Scholar

Matien, Y. A. (2016). Pengaruh Media Pendingin Terhadap Struktur Mikro, Kekerasan dan Laju Korosi Pada Hardening Baja Karbon Sedang. Universitas Negeri Semarang. Google Scholar

Mustofa, Z. (2016). Analisa Pengaruh Pendingin Terhadap Kekerasan Bahan Aisi 1045 Pada Proses Heat Treatment. Kediri: UN PGRI. Skripsi. Google Scholar

Nur, H. (2017). Pengaruh Penggunaan Media Pendingin Air Garam, Air Tawar, dan Air Asam pada Perlakuan Panas terhadap Kekerasan Baja ST 60. Teknik Mesin" Teknologi", 16 (1 Apr). Google Scholar

Putra, R. R., Jokosisworo, S., \& Santosa, A. W. B. (2018). Analisa Kekuatan Puntir, Kekuatan Tarik dan Kekerasan Baja ST 60 sebagai Bahan Poros Baling-baling Kapal (Propeller Shaft) setelah Proses Tempering. Jurnal Teknik Perkapalan, 6 (1). Google Scholar

Santoso, K., \& Suhardiman, S. (2019). Analisa Pengaruh Heat Treatment Terhadap Kekasaran Permukaan Benda Kerja Baja Karbon Rendah Pada Proses Pembubutan. Seminar Nasional Industri Dan Teknologi, 160-170. Google Scholar 
Setiawan, H. (2014). Pengujian kekerasan dan komposisi kimia produk cor propeler alumunium. Prosiding SNST Fakultas Teknik, 1 (1). Google Scholar

Slamet, U., \& Moelyono, D. G. (2000). Maximizing community benefits and minimizing environmental impacts in the Gunung Salak geothermal project, Indonesia. Proceedings of the World Geothermal Congress 2000. Google Scholar

Yusman, F. (2018). Pengaruh Media Pendingin Pada Proses Quenching Terhadap Kekerasan dan Struktur Mikro Baja AISI 1045. Google Scholar

\section{Copyright holder:}

Muhammad Syaifullah, Muhammad Subhan, Juanda (2021)

First publication right:

Jurnal Syntax Admiration

This article is licensed under:

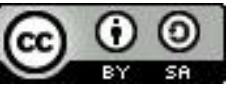

